\title{
Penggunaan E-System Dan Perilaku Kepatuhan Perspektif Wajib Pajak Karyawan
}

\author{
Meiliana Wikarsa ${ }^{1}$, Stephanie Febriana $\mathrm{Y}^{2}$, Pricillia Lanrence B ${ }^{3}$ \\ ${ }^{1,2,3}$ Universitas Kristen Petra Surabaya, Jl. Siwalankerto 121-131, Surabaya 60236
}

\section{A R T I C L E I N F O}

Key words:

e-system, e-SPT, Taxpayer Compliance Behaviour

\begin{abstract}
A B S T R A C T
In order to improve the quality of tax service on taxpayer, Direktorat Jendral Pajak implement an electronic system (e-SPT) in tax reporting. The purpose of this research is to interpret the perspective of the employees in the use of e-system in the reporting of SPT 1770 S and $1770 S S$ and taxpayer compliance behaviour of employee. Method used in this research is interpretive approaches. The data was collected by interviewing the employees. Based on the results of this research, can be concluded there are many of employee views on the use of e-SPT and the relation with tax compliance.
\end{abstract}

\begin{abstract}
A B S T R A K
Dalam rangka meningkatkan kualitas pelayanan pajak terhadap wajib pajak, Direktorat Jendral Pajak menerapkan sistem elektronik (e-SPT) dalam pelaporan pajak. Tujuan dari penelitian ini adalah untuk memaknai perspektif karyawan dalam penggunaan e-system dalam pelaporan SPT 1770 S dan $1770 S S$ serta perilaku kepatuhan wajib pajak karyawan. Penelitian ini mengunakan metode pendekatan interpretatif. Pengumpulan data dilakukan dengan wawancara terhadap karyawan. Berdasarkan hasil penelitian ini dapat disimpulkan bahwa terdapat berbagai macam pandangan karyawan terhadap penggunaan e-SPT dan adanya keterkaitan antara e-SPT dengan kepatuhan wajib pajak.
\end{abstract}

\section{PENDAHULUAN}

Penerimaan pajak adalah sumber penerimaan terbesar dan paling potensial untuk Negara Indonesia. Pajak tersebut akan digunakan untuk membiayai pemerintahan, pembangunan fasilitas dan prasarana, serta untuk kesejahteraan seluruh rakyat Indonesia. Pada tahun 1983, Indonesia melakukan tax reform, yaitu mengubah sistem pemungutan pajak dari official assessment menjadi self assessment. Perubahan sistem tersebut memberikan dampak bagi penerimaan pajak karena banyak wajib pajak yang menyalahgunakan kepercayaan yang diberikan untuk menghitung, menyetor dan melapor sendiri pajak terhutang mereka. Hal tersebut mengakibatkan penerimaan pajak tidak sesuai dengan yang direncanakan oleh pemerintah.

Untuk memaksimalkan penerimaan pajak di Indonesia, diperlukannya kerja sama antara wajib pajak dengan pemerintah. Pemerintah perlu meningkatkan kepercayaan wajib pajak terhadap sistem administrasi perpajakan yang berlangsung di Indonesia sehingga wajib pajak merasa perlu untuk membayar pajak. Caranya dengan menjalankan sistem pajak yang jujur dan transparan. Hal tersebut dapat meningkatkan kepatuhan wajip pajak. Begitu pula wajib pajak perlu untuk mendukung program yang dibuat oleh pemerintah agar bisa berjalan dengan baik dan sesuai rencana.

Beberapa tahun yang lalu, Direktur Jenderal Pajak (DJP) membuat program e-system. e-System adalah program yang bertujuan untuk memudahkan wajib pajak dalam hal melaksanakan kewajiban perpajakannya. Selain itu dengan adanya esystem, pemerintah dapat lebih mudah mengawasi kepatuhan wajib pajak dan juga kinerja dari pegawai pajak. e-System dapat dijalankan secara online. Ada berbagai macam e-system yaitu e-SPT, eFilling, e-Payment, e-Registration dan eCounceling.

Elektronik SPT atau e-SPT adalah aplikasi yang dibuat oleh Direktorat Jenderal (DJP) untuk digunakan oleh Wajib Pajak untuk kemudahan menyampaikan SPT. e-SPT memiliki beberapa kelebihan antara lain memudahkan dalam pelaporan

* Korespondensi Penulis: ${ }^{1}$ meili_wi@yahoo.com, ${ }^{2}$ stephaniefy9@gmail.com, ${ }^{3}$ pricillia.budianto@yahoo.com 
pajak, data perpajakan terorganisir dengan baik dan sistematis, panyampaian SPT dapat dilakukan secara cepat dan aman, dan menghindari pemborosan penggunaan kertas. Selain itu kelebihan e-SPT untuk pegawai pajak adalah tidak adanya pekerjaan yang diulang-ulang. Karena data yang dikirimkan wajib pajak menggunakan e-SPT langsung tersimpan dalam sistem kantor pajak sehingga pegawai pajak tidak perlu mengentri ulang data yang dilaporkan. Perekaman data secara manual oleh pegawai pajak juga memiliki beberapa kelemahan antara lain memakan sumber daya yang cukup banyak, kesalahan menginput angka, dan kesengajaan untuk memanipulasi data yang ada oleh pegawai pajak yang tidak memiliki itikad baik. E-SPT meminimalkan terjadinya kesalahan ataupun kecurangan yang dilakukan oleh pegawai pajak sehingga data wajib pajak lebih aman.

E-system diharapkan bisa menjadi solusi untuk meningkatkan kepatuhan pajak. Tetapi, jika dilihat dari prakteknya saat ini masih banyak wajib pajak yang tidak menggunakan fasilitas tersebut. Hal tersebut mungkin dikarenakan kurangnya pengetahuan akan adanya program e-system serta tidak semua wajib pajak mengerti cara menggunakan teknologi tersebut. Data pajak yang langsung tersimpan dalam sistem DJP juga membuat beberapa wajib pajak enggan menggunakan e-system. eSystem seakan-akan dihindari oleh wajib pajak, sehingga masih banyak wajib pajak yang lebih memilih untuk menggunakan cara tradisional untuk mengurus pajaknya. Seperti cara membayar, melaporkan dan mengisi SPT juga mendaftarkan diri sebagai wajib pajak (NPWP).

Berdasarkan latar belakang yang telah dijelaskan diatas, penulis ingin meneliti dan memaknai tentang penggunaan e-system dan perilaku kepatuhan perpektif wajib pajak karyawan. Penelitian ini dilakukan dengan tujuan untuk memaknai perspektif karyawan dalam penggunaan e-system dalam pelaporan SPT 1770 S dan 1770 SS serta perilaku kepatuhan wajib pajak karyawan. Penelitian ini nantinya akan menjelaskan bagaimana perspektif masing-masing karyawan tentang pemahaman mereka terhadap e-SPT, penggunaan e-SPT dalam pelaporan pajak mereka, perilaku kepatuhan yang berhubungan dengan penggunaan e-SPT, serta pentingnya penerapan e-SPT dalam pelaporan pajak di Indonesia.

\section{TINJAUAN PUSTAKA \\ Pengertian dan Fungsi Pajak}

Pajak mempunyai peranan yang sangat penting dalam kehidupan bernegara, khususnya di da- lam pelaksanaan pembangunan karena pajak merupakan sumber pendapatan negara untuk membiayai semua pengeluaran termasuk pengeluaran pembangunan. Definisi pajak menurut P. J. A. Adriani (1949), “Pajak adalah iuran masyarakat kepada negara (yang dapat dipaksakan) yang terutang oleh yang wajib membayarnya menurut peraturan-peraturan umum (undang-undang) dengan tidak mendapat prestasi kembali yang langsung dapat ditunjuk dan yang gunanya adalah untuk membiayai pengeluaran-pengeluaran umum berhubung tugas negara untuk menyelenggarakan pemerintahan." Pajak yang merupakan sumber penerimaan Negara mempunyai dua fungsi (Mardiasmo 2011 : 1), yaitu:

1. Fungsi anggaran (budgeter) sebagai sumber dana bagi pemerintah, untuk membiayai pengeluaran-pengeluarannya.

2. Fungsi mengatur (regulerend) sebagai alat pengatur atau melaksanakan pemerintah dalam bidang sosial ekonomi.

\section{e-System Perpajakan}

Di masa globalisasi saat ini, perkembangan teknologi di seluruh penjuru dunia sangatlah pesat. Perkembangan teknologi yang terjadi membuat segala sesuatu menjadi lebih mudah dan baik. Sektor perpajakan di Indonesia pun terkena dampak dari globalisasi ini. Buktinya, beberapa tahun lalu Direktur Jendral Pajak (DJP) menciptakan sistem modernisasi perpajakan yang disebut e-System. Menurut Liberti Pandiangan dalam bukunya "Modernisasi \& Reformasi Pelayanan Perpajakan", e-system merupakan suatu sistem yang digunakan untuk mendukung berjalannya modernisasi perpajakan dan dalam rangka peningkatan pelayanan kepada masyarakat maupun wajib pajak yang masih terus dikembangkan penerapan dan pemanfaatannya. e-System bertujuan agar semua proses kerja dan pelayanan perpajakan berjalan dengan baik, lancar, cepat, dan akurat. Dengan adanya e-system diharapkan penerimaan pajak dan kepatuhan pajak di Indonesia dapat meningkat. Terdapat beberapa macam e-system yang dapat digunakan dan dimanfaatkan oleh wajib pajak ataupun masyarakat antara lain e-Registration, e-SPT, e-Filling, dan ePayment.

\section{e-SPT}

Salah satu jenis dari e-system yang dapat dimanfaatkan dan diterapkan oleh wajib pajak adalah e-SPT. Menurut Liberti Pandiangan dalam bukunya "Modernisasi \& Reformasi Pelayanan Perpajakan", e-SPT adalah penyampaian SPT dalam ben- 
tuk digital ke Kantor Pelayanan Pajak (KPP) secara elektronik atau dengan menggunakan media komputer. Wajib pajak dapat melaporkan perhitungan pajaknya secara online menggunakan e-SPT tersebut. Banyak wajib pajak yang masih belum menggunakan e-SPT dalam pelaporan perhitungan perpajakannya. Wajib pajak masih merasa nyaman menggunakan SPT. SPT adalah surat pemberitahuan untuk melaporkan perhitungan pajak yang dilakukan oleh Wajib Pajak. e-SPT menurut jenis SPT nya dibagi menjadi dua, yaitu e-SPT PPh dan e-SPT PPN. Pelaporan pajak penghasilan yang saat ini menggunakan e-SPT adalah pajak penghasilan yang berasal dari karyawan (Wajib pajak yang menggunakan SPT 1770 S dan 1770SS). Sedangkan Wajib pajak yang menggunakan SPT 1770 masih belum disosialisasikan. Menurut Direktur Jendral Pajak, kelebihan dari e-SPT adalah sebagai berikut:

1. Penyampaian SPT dapat dilakukan secara cepat dan aman, karena lampiran dalam bentuk media $\mathrm{CD} /$ disket

2. Data perpajakan terorganisir dengan baik

3. Sistem aplikasi e-SPT mengorganisasikan data perpajakan perusahaan dengan baik dan sistematis

4. Penghitungan dilakukan secara cepat dan tepat karena menggunakan sistem komputer

5. Kemudahan dalam membuat Laporan Pajak

6. Data yang disampaikan WP selalu lengkap, karena penomoran formulir dengan menggunakan sistem komputer

7. Menghindari pemborosan penggunaan kertas (paperless)

8. Berkurangnya pekerjaan-pekerjaan klerikal perekaman SPT yang memakan sumber daya yang cukup banyak

\section{Perilaku Kepatuhan Wajib Pajak}

Sistem pemungutan pajak di Indonesia yang menggunakan sistem self-assessment membutuhkan perilaku kepatuhan pajak yang sangat tinggi karena wajib pajak dituntut ikut aktif dalam menyelenggarakan perpajakannya. Wajib pajak bertanggung jawab menetapkan sendiri kewajiban perpajakan kemudian secara akurat dan tepat waktu dalam membayar dan melaporkan pajaknya. Menurut Keputusan Menteri Keuangan No. 544/KMK.04/2000 dalam Sony Devano dan Siti Kurnia Rahayu (2006:112), menyatakan bahwa: "Kepatuhan perpajakan adalah tindakan Wajib Pajak dalam pemenuhan kewajiban perpajakannya sesuai dengan ketentuan peraturan perundang- undangan dan peraturan pelaksanaan perpajakan yang berlaku dalam suatu negara". Jenis-jenis kepatuhan pajak menurut Sony Devano dan Siti Kurnia Rahayu (2006:110) antara lain:

1) Kepatuhan formal adalah suatu keadaan dimana wajib pajak memenuhi kewajiban secara formal sesuai dengan ketentuan dalam Undang-undang perpajakan

2) Kepatuhan material adalah suatu keadaan dimana wajib pajak secara substantif/hakikatnya memenuhi semua ketentuan material perpajakan yaitu sesuai isi dan jiwa undang-undang pajak kepatuhan material juga dapat meliputi kepatuhan formal.

\section{Hubungan Teknologi Informasi Perpajakan dan Perilaku Kepatuhan Wajib pajak}

Kepatuhan pajak saat ini di Indonesia dapat dikatakan masih rendah. Tingat kesadaran wajib pajak (Taxpayer's awareness) akan pentingnya pajak juga rendah. Ada beberapa faktor lain juga yang mempengaruhi tingkat kepatuhan wajib pajak, salah satunya kemudahan dalam pelaksanaan kewajiban perpajakan. Pelaksanaan dan pelayanan pajak di Indonesia yang rumit dan belum optimal membuat banyak wajib pajak yang tidak patuh dalam melaksanakan kewajiban perpajakannya. Kepatuhan pajak yang rendah berdampak juga pada penerimaan negara. Modernisasi perpajakan bertujuan untuk memberikan kemudahan dalam segala aktivitas perpajakan baik dari segi wajib pajak maupun dari segi petugas pajak. Dari segi wajib pajak, dengan adanya sistem perpajakan yang semakin memberikan kemudahan, keinginan wajib pajak untuk melaksanakan kewajiban perpajakannya dengan baik dan sesuai peraturan yang ada diharapkan akan semakin tinggi. Sedangkan dari sisi petugas pajak, para petugas pajak dapat lebih mudah mengawasi aktivitas perpajakan wajib pajak.

Berdasarkan penelitian oleh Mohamad Havid (2014) yang berjudul Pengaruh Penerapan e-Filling Terhadap Tingkat Kepatuhan Wajib Pajak (Studi Survey Pada KPP Pratama Bandung Cibeunying), disimpulkan bahwa penerapan e-filling dengan tingkat kepatuhan pajak berhubungan positif, jika penerapan e-filling semakin baik maka tingkat kepatuhan pajak juga semakin tinggi; penelitian oleh Toma Yanuar Putra (Jurnal Mahasiswa Perpajakan Vol. 6, No. 1, 2015) yang berjudul Pengaruh Penerapan Sistem Administrasi eRegistration, e-SPT dan e-Filling Terhadap Tingkat 
Kepatuhan Wajib Pajak (Studi Pada Wajib Pajak di Kantor Pelayan Pajak Pratam Singosari), disimpulkan bahwa e-Registration, e-SPT dan eFilling berpengaruh terhadap tingkat kepatuhan wajib pajak; dan penelitian oleh Nita Rysaka, Choirul Saleh, Stefanus Pani Rengu (Jurnal Administrasi Publik, Vol. 2. No. 3, Hal.420-425) yang berjudul Penerapan Sistem Elektronik dalam Pelayanan (Studi Pada Kantor Pelayanan Pajak Pratama Malang Utara), disimpulkan bahwa penggunaan sistem elektronik dapat mempermudah perhitungan yang dilakukan secara cepat dan tepat dalam melaporkan pajak dengan menggunakan sistem komputer sehingga dapat memberikan kemudahan. Dari penelitianpenelitian diatas yang telah dilakukan dan diuji oleh beberapa peneliti dapat dilihat bahwa teknologi informasi perpajakan memberikan kemudahan dalam pelaksanaan kewajiban pajak serta memiliki pengaruh dan hubungan dengan tingkat kepatuhan pajak.

\section{METODE PENELITIAN Metode Penelitian}

Dalam penelitian ini yang dibuat untuk memaknai penggunaan e-system dan perilaku kepatuhan perspektif wajib pajak karyawan, penulis menggunakan pendekatan yang bersifat kualitatif. Untuk mencapai pemahaman yang mendalam, peneliti menggunakan paradigma interpretatif untuk penelitian ini. Pendekatan interpretatif adalah sebuah sistem sosial yang memaknai perilaku secara detail langsung mengobservasi (Newman, 1997:68). Dengan menggunakan pendekatan interpretatif, peneliti dapat melihat fenomena dan menggali secara mendalam perspektif dan pengalaman dari narasumber/informan.

\section{Informan dan Pengumpulan Data}

Informan yang dipilih dalam penelitian ini adalah wajib pajak karyawan yang mengerti tentang pajak dan melaporkan pajak menggunakan SPT 1770SS atau 1770S baik secara manual ataupun elektronik. Objek penelitian ini adalah dua orang karyawan yang bekerja di Universitas swasta dan satu orang karyawan yang bekerja di Bank. Nama Informan yang dicantumkan adalah nama alias atau bukan nama sesungguhnya. Pengumpulan data dilakukan dengan wawancara mendalam kepada informan untuk mendapatkan informasi yang akan mendukung penelitian. Menurut Sutrisno Hadi (1989:192) wawancara suatu proses tanyajawab lisan, dalam mana dua orang atau lebih berhadap-hadapan secara fisik, yang satu dapat meli- hat muka yang lain dan mendengarkan dengan telinga sendiri suaranya, tampaknya merupakan alat pemgumpulan informasi yang langsung tentang beberapa jenis data sosial, baik yang terpendam (latent) maupun yang memanifes.

\section{Analisis Data}

Dalam penelitian ini, terdapat empat tahap yang digunakan dalam menganalisis data. Tahapan tersebut antara lain: (1) Pengumpulan data; (2) Reduksi data; (3) Interpretatif data; dan (4) Penarikan kesimpulan

\section{ANALISIS DAN PEMBAHASAN \\ Pemahaman karyawan terhadap e-SPT}

Ibu Lani yang merupakan seorang karyawan swasta mengungkapkan pemahamannya tentang pengertian e-SPT sebagai

"e-SPT itu untuk melaporkan pajak lewat komputer gitu, kalau SPT biasa itu kan pakai kertas ya tapi kalau e-SPT nginput-ngiputnya di komputer gitu."

Ibu Lani memahami e-SPT sebagai sebuah fasilitas yang digunakan dalam mengungkapkan pajak yang terhutang melalui media elektronik. Kemajuan perkembangan teknologi juga mempengaruhi perkembangan sistem pelaporan pajak di Indonesia. eSPT juga digambarkan sebagai bentuk yang lebih canggih dibandingkan SPT manual, dikarenakan pengisian datanya tidak lagi dilakukan pada lembaran-lembaran kertas tetapi pada media elektronik. Sehingga dapat dikatakan e-SPT ramah lingkungan karena minim dalam penggunaan kertas.

"Suatu sistem yang digunakan untuk pelaporan pajak perorangan maupun perusahaan"

Pak william memahami e-SPT sebagai sebuah program atau metode yang digunakan untuk menyampaikan pajak dari suatu badan atau individu

"Sistem pelaporan yang diterapkan oleh pemerintah supaya DJP lebih mudah dan lebih ketat untuk mengawasi Wajib Pajak."

Pak Dani menganggap bahwa e-SPT adalah salah satu metode untuk melaporkan pajak yang diaplikasikan kepada wajib pajak yang bertujuan untuk membuat pekerjaan DJP lebih praktis dan pengawasan terhadap wajib pajak lebih intensif.

\section{Penggunaan e-SPT dalam pelaporan pajak}

"Saya pakai e-SPT. Ya enak to sudah ada fasilitas kita tinggal ngisi-ngisi, tinggal klik-klik aja, tinggal dimasukkan kan sudah otomatis nggak perlu nulis-nulis. Ya saya cari gampangnya aja, dulu udah disosialisasikan disini suruh pakai e-SPT ya kita pakai aja kan lebih gampang. Saya suami saya se- 
mua pakai e-SPT."

Ibu Lani lebih memilih menggunakan e-SPT dalam pelaporan kewajiban perpajakannya dikarenakan beliau menganggap e-SPT menyediakan sarana pengisian dan pelaporan data-data yang meringankan beban wajib pajak dalam melakukan tugasnya. Wajib pajak tidak perlu menuliskan lagi satu-satu angka kedalam kolom yang ada, hanya tinggal menginput di dalam komputer yang bisa meminimalkan kesalahan dalam penghitungan. Kemudahaan yang dirasakan Ibu Lani dan sekeluarga membuat mereka lebih tertarik menggunakan cara modern ini. Adanya pengaruh dari lingkungan yang mengharuskan penggunaan e-SPT juga menjadi salah satu dorongan untuk beliau dalam menggunakan sistem tersebut.

"pakai sih, kan lebih praktis dan gak ribet, arsip sing lama- lama gampang dicari soale sudah tersimpan secara digital, apalagi buat orang yang sibuk kerja berguna banget, isa dibuka dimana ae gak harus ke kantor pajak tinggal masukin password e ae"

Pak william lebih memilih menggunakan e-SPT dalam menyampaikan kewajiban pajaknya karena beliau menganggap e-SPT memberikan kemudahan dalam pengisiannya selain itu data - data yang lama mudah ditelusuri karena sudah tersimpan secara otomatis dan menganggap sangat bermanfaat bagi beliau yang aktif karena dapat di akses dimana saja tanpa harus ke kantor pajak.

"Saya pakai manual, soale aku ora seneng wong aku diawasi lebih ketat, nek kowe tak awasi gerakgerikmu gelem nggak? Saya juga gak terlalu senang kalau SPT saya itu dibuka oleh orang, kan isinya merupakan privilege kita."

Terdapat perbedaan dalam pendapat pak Dani dengan informan yang lainnya. Pak Dani lebih memilih untuk tidak memakai e-SPT, karena semua data yang dilaporkan didalam SPT tersimpan didalam database, sehingga memudahkan DJP dalam mengakses data-data yang lama. Menurut pak Dani semua data tersebut merupakan hak istimewa beliau yang tidak boleh disebarluaskan. Beliau juga tidak senang karena semua gerak-gerik beliau diamati oleh DJP. Menurut peneliti, pak Dani ada indikasi melakukan kecurangan dalam menjalankan kewajiban perpajakannya, dikarenakan pak Dani yang sangat bersikeras dalam mengatakan pendapatnya dalam hal keengganannya memakai e-SPT yang disebabkan oleh pengawasan yang dilakukan oleh DJP secara intensif.

\section{Pemanfaatan e-SPT}

"Ya perlu sih ya, soalnya kan ya itu lebih gampang, nggak usah repot-repot nulis lagi, ngitung lagi. Pemerintah udah kasih fasilitas gitu ya kita harus pakai. Ga perlu lah takut data-data kita kesimpen di DJP. Kalau saya sih ga takut ngapain takut."

e-SPT dianggap perlu oleh Ibu Lani untuk digunakan dalam pelaporan pajak bagi wajib pajak. Seperti alasan beliau menggunakan e-SPT, beliau juga mengatakan bahwa perlunya penggunaan eSPT bagi wajib pajak dikarenakan kemudahan yang ditawarkan serta praktis dalam penerapannya. Ibu Lani berpendapat bahwa e-SPT merupakan hasil kerja pemerintah yang wajib digunakan. Hal tersebut mungkin dikarenakan sudah menjadi suatu keharusan sebagai wajib pajak Indonesia untuk mengikuti segala aturan yang berlaku. Selain itu banyak wajib pajak yang enggan menggunakan e-SPT karena takut record-nya tersimpan semua, tetapi Ibu Lani tidak memperlihatkan ketakutan tersebut. Sehingga peneliti berpendapat bahwa Ibu Lani merupakan wajib pajak yang menjalankan kewajiban perpajakannya dengan baik dan patuh terhadap peraturan yang berlaku.

“Kalau buat aku sing sibuk sih perlu kan lebih praktis, efisien dan efektif dari segi biaya,waktu maupun tenaga gak perlu ke kantor pajak terus nunggu lama-lama. Kalau manual kan harus ke kantor DJP, aku ya males datang kesana terus harus nunggu lama, lagian kadang gak ada waktu buat kesana."

Menurut pak William yang aktif dalam bekerja e-SPT itu perlu karena memberikan kemudahan dan benefit yang banyak dari berbagai aspek seperti ekonomi, peluang, dan energi. Pak William juga berpendapat bahwa pengisian SPT secara tradisional sangat merepotkan dikarenakan keharusan untuk mendatangi kantor pajak dan mengantri panjang jika saat batas waktu pelaporan. Beliau juga sangat sibuk, oleh karena itu beliau susah mencari waktu untuk pergi ke kantor pajak di hari kerja atau sebelum batas waktu pelaporan. Menurut peneliti, pak William akan patuh terhadap kewajiban perpajakannya jika menggunakan e-system dalam pelaporan pajaknya.

"Menurut saya gak perlu, soale gak semua Wajib Pajak ngerti cara pake internet atau komputer, padahal tujuannya untuk memudahkan, malah justru menyusahkan Wajib Pajak dalam melaporkan pajaknya jika diwajibkan menggunakan e-SPT."

Menurut pak Dani, e-SPT tidak diperlukan untuk menjadi sistem pelaporan pajak yang wajib di Indonesia. Beliau juga berpendapat bahwa tidak 
semua warga di Indonesia mengerti cara menjalankan program e-SPT tersebut, contohnya orang yang sudah lanjut usia atau orang yang tempat tinggalnya terletak di desa, dll. Tujuan semula dibuatnya e-SPT adalah untuk memudahkan wajib pajak dalam melaporkan pajaknya dan membuat wajib pajak senang dalam melaksanakan kewajiban perpajakannya, tetapi e-SPT justru menyulitkan wajib pajak dan membuat wajib pajak malas dalam melaksanakan kewajiban perpajakannya. Menurut peneliti, e-SPT ditujukan untuk generasi muda yang kemungkinan besar mengerti dalam menggunakan internet dan komputer, untuk yang tidak mengerti pemerintah harus melakukan kampanye di tempat-tempat yang terpencil.

\section{SIMPULAN}

Berdasarkan hasil penelitian dengan ketiga informan, peneliti dapat menarik kesimpulan bahwa terdapat beberapa pandangan karyawan terhadap e-system, khususnya e-SPT 1770 S dan 1770SS dan keterkaitannya dengan kepatuhan wajib pajak. Ibu Lani memahami e-SPT sebagai fasilitas dari pemerintah untuk melaporkan pajak melalui media elektronik yang memberikan kemudahan terhadap wajib pajaknya. Ibu Lani menggunakan e-SPT karena merasa dipermudah dalam proses pelaporan pajaknya. Ibu Lani juga tidak takut dengan kemudahan pemerintah dalam mengakses data-data beliau yang lama. Dapat disimpulkan ibu Lani termasuk wajib pajak yang sudah patuh terhadap kewajiban perpajakannya.

Pak William mempunyai pemahaman yang hampir sama dengan ibu Lani, yaitu e-SPT merupakan sistem untuk melaporkan pajak orang pribadi maupun badan dan penggunaan e-SPT memberikan kemudahan terhadap pelaporan pajaknya. Pak William senang dalam menggunakan e-SPT karena lebih efisien dan menghemat waktu dan biaya. Sehingga dapat dikatakan pak William termasuk wajib pajak yang patuh.

Pak Dani mempunyai memahami bahwa e-SPT adalah sistem pelaporan pajak yang diterapkan oleh pemerintah untuk membuat DJP lebih mudah dan ketat dalam pengawasan terhadap wajib pajak. Tetapi pak Dani mempunyai pemahaman yang berbeda terhadap pemanfaatan e-SPT, beliau merasa e-SPT tidak diperlukan karena tidak semua kalangan di Indonesia mengerti cara menggunakan e-SPT tersebut. Beliau juga mengatakan bahwa ia tidak senang menggunakan e-SPT dikarenakan ketidakinginan para petugas pajak bisa mencari data-data beliau yang sudah lama. Sehingga dapat disimpulkan perilaku kepatuhan pak Dani perlu dipertanyakan.

\section{DAFTAR PUSTAKA}

Devano, Sony dan Rahayu, Siti Kurnia. 2006. Perpajakan: Konsep, Teori, dan Isu. Satu, Jakarta.

Pandiangan, Liberti. 2008. Modernisasi dan Reformasi Pelayanan Perpajakan. PT Elex Media Komputindo, Jakarta.

Havid, Mohamad. 2014. "Pengaruh Penerapan eFilling Terhadap Tingkat Kepatuhan Wajib Pajak (Studi Survey Pada KPP Pratama Bandung Cibeunying)". Skripsi Universitas Widyatama, Bandung.

Putra, Tomy Yanuar. 2015. "Pengaruh Penerapan Sistem Administrasi e-Registration, e-SPT dan e-Filling Terhadap Tingkat Kepatuhan Wajib Pajak (Studi Pada Wajib Pajak di Kantor Pelayan Pajak Pratam Singosari)". Jurnal Mahasiswa Perpajakan Vol. 6, No. 1.

Nita, Choirul, Stefanus P.R. 2014. "Penerapan Sistem Elektronik dalam Pelayanan (Studi Pada Kantor Pelayanan Pajak Pratama Malang Utara)". Jurnal Administrasi Publik, Vol. 2. No. 3:420-425.

Ricki, Haris, dan Mujilan. 2013. “Modernisasi Sistem Administrasi Perpajakan dan Kepatuhan Wajib Pajak". Jurnal Riset Manajemen dan Akuntansi (JRMA); Vol. 1 No. 1, Februari 2013. 


\section{LAMPIRAN}

\section{Transkip Wawancara}

\section{Bu Lani}

Ibu tahu e-SPT nggak?

- Iya tau.

Menurut Ibu e-SPT itu apa?

- $\quad$-SPT itu untuk melaporkan pajak lewat komputer gitu, kalau SPT biasa itu kan pakai kertas ya tapi kalau eSPT nginput-ngiputnya di komputer gitu.

Apakah Ibu menggunakan e-SPT?

- Saya pakai e-SPT. Ya enak to sudah ada fasilitas kita tinggal ngisi-ngisi, tinggal klik-klik aja, tinggal dimasukkan kan sudah otomatis nggak perlu nulis-nulis. Ya saya cari gampangnya aja, dulu udah disosialisasikan disini suruh pakai e-SPT ya kita pakai aja kan lebih gampang. Saya suami saya semua pakai e-SPT.

Kan banyak orang nggak mau pake e-SPT gara-gara datanya semua tersimpan di DJP, apa ibu ngga takut?

- $\quad$ Lhaa ngapain takut? Hahaha kalau pake SPT ya pasti datanya kesimpan juga di DJP.

Tapi kalau pake e-SPT itu lebih gampang dicari datanya bu..

- Oo ya gapapa, ga usah takut kalau emang gaada main-main

Lalu menurut ibu apaka perlu penggunaan e-SPT ini buat pelaporan pajak?

- Ya perlu sih ya, soalnya kan ya itu lebih gampang, nggak usah repot-repot nulis lagi, ngitung lagi. Pemerintah udah kasih fasilitas gitu ya kita harus pakai. Ga perlu lah takut data-data kita kesimpen di DJP. Kalau saya sih ga takut ngapain takut

\section{Pak William}

Apakah bapak mengetahui e-SPT?

- Tau

Menurut bapak, apa e-SPT itu?

- $\quad$ suatu sistem yang digunakan untuk pelaporan pajak perorangan maupun perusahaan.

Apakah bapak menggunakan e-SPT? Apa alasan bapak menggunakannya atau tidak menggunakannya?

- $\quad$ pakai sih, kan lebih praktis dan gak ribet, arsip sing lama-lama gampang dicari soale sudah tersimpan secara digital, apalagi buat orang yang sibuk kerja berguna banget, isa dibuka dimana ae gak harus ke kantor pajak tinggal masukin password e ae

Menurut bapak, apakah e-SPT itu perlu?

- Kalau buat aku sing sibuk sih perlu kan lebih praktis, efisien dan efektif dari segi biaya,waktu maupun tenaga gak perlu ke kantor pajak terus nunggu lama-lama. Kalau manual kan harus ke kantor DJP, aku ya males datang kesana terus harus nunggu lama, lagian kadang gak ada waktu buat kesana.

Pak Dani

Apakah bapak mengetahui program DJP yang baru, e-SPT?

- Ya, saya tau

Menurut bapak, e-SPT itu apa?

- $\quad$ Sistem pelaporan yang diterapkan oleh pemerintah supaya DJP lebih mudah dan lebih ketat untuk mengawasi Wajib Pajak.

Apakah bapak menggunakan e-SPT?

- Saya pakai manual

Apakah alasan bapak tidak menggunakan e-SPT?

- Soale aku ora seneng wong aku diawasi lebih ketat, nek kowe tak awasi gerak-gerikmu gelem nggak? Saya juga gak terlalu senang kalau SPT saya itu dibuka oleh orang, kan isinya merupakan privilege kita.

Diawasi lebih ketat bagaimana maksud bapak?

- Data saya yang lama bisa dicari dengan gampang oleh DJP, tinggal di search nama Dani kan langsung muncul data-data saya dari tahun yang lama sampai sekarang. Kalau manual DJP masih lebih susah mencari data-data saya yang sudah lama

Menurut bapak, apakah e-SPT itu perlu?

- $\quad$ Menurut saya gak perlu, soale gak semua Wajib Pajak ngerti cara pake internet atau komputer, padahal tujuannya untuk memudahkan, malah justru menyusahkan Wajib Pajak dalam melaporkan pajaknya jika diwajibkan menggunakan e-SPT. 